\title{
Framing Analysis on Public Crisis Communication by the Ministry of Health during COVID-19 Outbreak
}

\author{
Precy Setyadhika Permata ${ }^{1 *}$
}

\author{
${ }^{1}$ Faculty of Social and Political Sciences, Universitas Atma Jaya, Yogyakarta, Indonesia \\ *Corresponding author.Email: precy.permata@gmail.com
}

\begin{abstract}
This research is a qualitative descriptive research aiming to get an explanation about the process of reality reconstruction done by online media and various kind of framing devices used at detik.com and kumparan.com reporting about Crisis Communication caused by Ministry of Health, Terawan Agus Putranto, in response to the COVID-19 outbreak. In its execution, this research was using a framing analysis method to gain information about the way of online media's telling story. The data were collected using qualitative content analysis applied to detik.com and kumparan.com articles published during March-April 2020. The unit of analysis was determined based on Pan and Kosicki framing analysis model. Data validity was measured by the triangulation technique. Data analysis was conducted using the interactive data analysis technique. The result of research shows that detik.com and kumparan.com have a different point of view in reconstruction in this case. Detik.com showed careful, details, and firm news reporting, while kumparan.com is much lighter and moderate. Both online media use the same framing devices, including syntactic, script, thematic, and rhetoric. In representing Terawan Agus Putranto as Minister of Health, detik.com and kumparan.com are tending to frame him as an incompetent person to deliver messages about COVID-19 in Indonesia to their public.
\end{abstract}

Keywords: Crisis Communication, COVID-19, Ministry of Health, Framing Analysis, Online Media

\section{INTRODUCTION}

Since the end of 2019, when it was first discovered in Wuhan, China, the spread of the Coronavirus has become more widespread and has become a serious threat to the global world and has infected nearly a quarter of a million people. Inadequate knowledge about this virus has resulted in an increasingly extreme spread to all parts of the world. This Coronavirus usually infects birds and mammals as well as humans. Compiled from the official account https://www.who.int/, the cause of this outbreak is said to be a new type of Coronavirus, namely the 2019 coronavirus novel with the official name 2019-nCov. This virus can attack anyone, from babies, kids, adults, pregnant women to the elderly. This virus has also been declared as a pandemic by WHO because it has been included into a disease outbreak that has a continuous line of infection or is easily transmitted.

The World Health Organization (WHO) explains that the spread of this virus is classified as very fast because it can last for hours outside the body. Humanto-human transmission of this virus can occur through direct contact at close range, for example, when respiratory droplets the sufferers produce when coughing or sneezing. Symptoms that arise due to this virus are mild and occur gradually. However, many people who have been confirmed positive for this virus do not show such symptoms as fever, fatigue and dry cough like the common symptoms of Covid-19. 
This virus easily spreads on exposed surfaces, such as door handles, tables, and even cell phones that have been touched by an infected person. Because of its very rapid spread, this virus also started to spread to Indonesia last March. However, since President Joko Widodo announced the first patient who has been confirmed positive Covid-19, there have been many criticisms made by the public regarding the inaccuracy of information and the identity of the victim being revealed. Communication problems in government agencies have not improved, because the public already does not trust any information issued by the government and tends to seek from other sources such as the internet, especially social media.

The challenges faced by Indonesia today are the character of its diverse society, namely a lack of discipline, a low level of compliance with government recommendations and an increasingly urgent economic condition. Of the total community actions, this is due to the lack of seriousness and inconsistency of the information provided by the government to the community. Especially when, the Minister of Health, Terawan Agus Putranto, seems to underestimate the Coronavirus at the beginning of its appearance in media as common coughs and not a terrifying thing [1].

Previously, the Minister of Health also said that Indonesians were not vulnerable to this outbreak. In addition, the government, especially the Ministry of Health, appears to have underestimated this outbreak and equated it with the spread of the common cold virus. In fact, the Minister of Health has plenty of time to conduct research, especially conducting research with other countries that have been infected by this virus and how to handle it so that we can anticipate if this outbreak comes to Indonesia. In addition, a health expert from Harvard University has warned Indonesia since February about the weak procedures for early detection of the Corona outbreak in Indonesia.

Moreover, the government is also not ready with a protocol for using masks for the community. When the first positive case of Corona positive patients entered Indonesia, panicked and confused people finally flocked to buy masks, hand sanitizers and food ingredients, causing scarcity. In response to this, the government recommends wearing masks only for sick people and health workers who treat Covid-19 patients. Masks are only intended to sick people, while people who are in good health are advised to take care of themselves by increasing their immunity [2].

This maze of government statements received the attention of the mass media, which intensified reporting of a public communication crisis by the Indonesian government, especially statements made by the Minister of Health, Terawan Agus Putranto, who tended to underestimate the outbreak. Even so, the media seems to ignore that facts or negative news can affect the public psychologically. Statements published in the mass media about government actions in dealing with the Covid-19 case have had a major influence on the formation of public opinion so that people have their own reactions to the news they receive. This is inseparable from the big role of the media, because it is not uncommon for media opinion to become public opinion.

In this research study, researchers used framing analysis on online media coverage of the Ministry of Health's communication crisis in responding to Covid19, especially by the Indonesian Minister of Health, Terawan Agus Putranto at detik.com and kumparan.com with a span of March-April 2020. These two online media was selected because they both had different news characteristics and orientations, but the uniqueness of these two media was that they were founded by the same person, namely Budiono Darsono. Quoted from the detik.com site, this media is oriented to the speed at which its news will decline by selecting firm and accurate word choices. The news published on detik.com is also written in a language that is easily understood by the public.

It is in contrast to kumparan.com, which calls itself a digital startup that has a minimalist, firm and straightforward appearance by presenting light news and looking more relaxed. Uniquely, Kumparan.com was also founded by Budiono Darsono, who was also the founder of detik.com. Kumparan.com's consistency in combating the spread of fake news (hoax), hate speech and other negative content is that it has a special team that constantly filters incoming news content so that readers don't have to worry about hoax or negative content.

Therefore, based on the above explanation, this research is interesting to do to find out how the media frames public communication that occurs at the Ministry of Health, especially by the Minister of Health in responding to the Covid-19 issue on detik.com and kumparan.com.

\section{LITERATURE REVIEW}

\subsection{Mustika, R. 2017. Analysis of Online Media Coverage Framing Regarding Pedophilia Cases on Facebook Accounts.}

Based on research conducted by Mustika (2017) entitled "Analysis of Online Media Reporting Framing Regarding Pedophilia on Facebook Accounts," it is known that researchers used two online media as research subjects, namely Kompas.com and Republika Online [3]. This study aims to get an overview of how 
Kompas.com and Republika Online frame the reporting of pedophilia cases via Facebook accounts using the same conceptual foundation, namely a brief explanation of online news media, constructs produced by the media, Framing Theory with Robert N. Entman's Model. as well as an explanation of the Pedophilia Group case findings on the Facebook account.

Data collection was obtained by downloading news about pedophilia through a Facebook account posted on the news portal Kompas.com and Republika Online during the period March-April 2017. The author then groups the news based on the Robert N. Entman model by dividing it into four categories; what problems occur, the causes of problems, moral concerns, and suggestions or solutions given.

The difference with the research that will be carried out by the researcher is the framing analysis model used, the Zhongdang Pan and Kosicki model in which the framing device can be categorized into four major structures: Syntax, Script, Thematic and Rhetorical. The use of the Zhongdang Pan and Kosicki model fits this research because it will reveal the framing carried out by the media in more detail from the reporter's point of view, the language written down to the implied intent of the news presented to the reader until the framing is formed.

2.2. Athalia, M., Purnama, Hadi, Nugroho, Chess. 2017. Analysis of the News Framing of the Construction of the Jakarta-Bandung Fast Train.

This journal article discussed the news about the Jakarta-Bandung fast train on online media metrotvnews.com and also viva.co.id. Basically, the background content of the problems presented is almost the same as Rieka Mustika. The explanation conveyed also about the media has contributed to the formation of public opinion through the reporting frame carried out by each media [4].

But the difference lies on the analysis in this journal article using the Pan and Kosicki model which is often used. The reason the authors used this model was because this model has more complete elements than other framing models. The shortage of analysis part in this journal article is that it did not display detailed news titles for analysis from each media. The author only displayed the number of news broadcasts on the two news portals. There are at least 46 news about the groundbreaking of the fast train on the news portal metrotvnews.com and 34 news on viva.co.id. In addition, the analysis was not carried out sequentially based on the structure presented by Pan and Kosicki such as Syntax, Script, Thematic and Rhetoric so that journal article readers were confused when reading.
However, the results obtained from this journal show that these two media portals are not objective in framing a story. This is related to the owner of each media engaged in politics. Metrotvnews.com belongs to Surya Paloh, who is a supporter of the government, while viva.co.id is owned by Bakrie, who is known to be in opposition to the current government. The framing of the news on the two news portals seems more eager to explore regulatory aspects or permit issues in the construction of this fast train.

\section{METHODS}

\subsection{Types of research}

This research, according to the type of research, is descriptive qualitative. This qualitative research aims to explain existing phenomena in depth through data collection. Research using a qualitative descriptive approach aims to construct propositions or explain hidden meanings behind reality. The effort made in this research was to look at what is happening in the world and put the field findings obtained in it [5].

Therefore, the qualitative approach causes a scope that cannot be generalized because the data collected is in the form of words, pictures and not numbers [6]. In general, the research using this type has the following characteristics: intensive, long-term participation of researchers in field settings, researchers are the main research instruments. The recording of what happens was made very carefully with notes on the ground and other types of documentary evidence available, analysis of field data.

\subsection{Research methods}

This study used the framing analysis method. It was explained that framing analysis is an analysis used to construct reality. This analysis was also used to see how an event is trying to be framed and understood by the media [7].

From a communication perspective, framing analysis is also used to dissect the ways and ideology of a media in delivering it to the public by constructing existing facts. Framing analysis is simply described as an analysis to find out how reality (events, actors, groups, or whatever) is framed by the media. The role of the media in framing analysis is seen as part of a broader public discussion. How do these media frame and package certain messages to the audience and how political participants interpret and construct events to be presented to the public. The public also carries out 
different processes and interpretations of an issue or event [8].

Of the many framing analysis models, this study used the Zhongdang Pan and Kosicki model because this model is one of the most frequently used models. In this approach, framing devices can be categorized into large structures.

First, the syntactic structure deals with how journalists organize events, statements, opinions, quotes, observations of events into the general structure of a story. This semantic structure can be seen from the news chart (used leads, background, headlines, quotes and so on).

Second, the script structure deals with how journalists tell events in the form of news that can be enjoyed by the public. This structure also looks at how the storytelling strategies and methods are used by journalists to package news.

Third, the thematic structure is related to how journalists convey their views on an event into propositions, relationships between sentences or sentences so as to form a complete text.

Fourth, the rhetorical structure deals with how journalists emphasize a particular point in a story. In this structure, we can see the journalist choosing the graphic words, idioms and images that are used not only to support the writing, but also to emphasize on a certain meaning for the reader. That way the tendency of journalists or a media institution can be observed through these four structures [9].

\subsection{Data Sources}

The data source in this research is news text obtained from two online media, namely detik.com and kompas.com from March to April 2020. The date limitation on data collection is intended to make it easier to perform data analysis and also in that time span is the beginning.

\section{RESULT AND DISCUSSION}

\subsection{Findings and Discussion}

From the two online media, the researchers found at least 3 (three) news stories on detik.com and 3 (three) news on kumparan.com showing a public communication crisis conveyed by the Minister of Health, Terawan Agus Putranto, leading to public panic.
Three news headlines on detik.com that will be analyzed include:

1. "Minister of Health Terawan Affirms Masks Only For Sick People"

2. "Minister of Health Terawan: Treatment of Coronavirus Patients Like People with Flu"

3. "Minister of Health: Corona is not a scary item, I am confident"

Meanwhile, three other news headlines on kumparan.com that will be analyzed are:

1. "Minister of Health: If you are healthy, don't use a mask"

2. "Terawan: Treatment of CoronaVirus Patients Like People with Flu"

3. "Terawan: Flu Death Rate is Higher, Why is Corona Outbreaking?"

\subsection{Analysis of the Reporting Framing of the Ministry of Health in handling COVID-19 cases in Detik.com and Kumparan.com}

\subsubsection{Syntax}

The first aspect, namely syntax, emphasizes on the preparation of a news scheme which includes headlines, leads, background information, quotes, sources, statements and closings.

At detik.com, from the title displayed, it seems that more emphasis is placed on Terawan's position as Minister of Health who has the responsibility to provide the latest information on the development of the COVID-19 case in Indonesia and hopes that the public will not panic with news about Coronavirus that appears in various media.

From the titles raised by detik.com, it can be estimated that detik.com wants to emphasize how the reaction of the Minister of Health, Terawan Agus Putranto, responded to the emergence of the first Coronavirus case that emerged in Indonesia. Based on the statement that Terawan always expressed, Corona is not so scary because it is just like flu symptoms and there is no need to use a mask if you don't experience symptoms to prevent the scarcity of masks. In addition, the title displayed by detik.com has a tendency to convince the public with a firm language style. In fact, this is increasingly being questioned by the public 
because when we look back at the reality on the ground, Corona cases are increasing day by day and are not the same as ordinary flu cases as said by the Minister of Health.

In contrast, Kumparan.com, the title displayed on each news item seems lighter with today's typical language. This can be seen from the titles, namely "Minister of Health: If you are healthy, don't wear a mask", "Terawan: Treatment of CoronaVirus Patients Like People with the Flu", and "Terawan: The Death Rate of Flu is Higher, Why is Corona Amazing?". The editorial policy of kumparan.com, which is an elaboration of Kumparan's vision, is to deliver light news and seem more relaxed for readers. It appears that the title displayed by kumparan.com more often mentions Terawan as a person than the Minister of Health.

Regarding the selection of sources, in contrast to detik.com which only featured the Minister of Health, Terawan Agus Putranto as the only resource, Kumparan.com provided space for Achmad Yurianto, who was appointed to be the spokesman for the Government in handling the Corona case in Indonesia to speak out.

\subsubsection{Script}

This aspect includes how journalists tell the facts seen from the completeness of the $5 \mathrm{~W}+1 \mathrm{H}$. Detik.com in its reporting has used the complete $5 \mathrm{~W}+1 \mathrm{H}$ elements. However, detik.com focuses more on what and how aspects related to how Terawan Agus Putranto tries to ensure that the Corona virus is not a terrible virus and should be feared.

This is commonly done in the world of journalism, especially in framing an event. As stated by Eriyanto [10], framing is generally characterized by obscuring certain aspects and emphasizing other aspects as in the following detik.com news:

Minister of Health Terawan Agus Putranto assured that the Corona virus is not a scary thing. Terawan also admitted that he was very confident in dealing with this deadly virus. (what)

Yes, it depends on where we all want to go, what we want, what is clear is that the government is honest and always what it is. You see the Minister of Health is very confident, sure what to deal with. (how)

From the statement above, the researchers interpreted Terawan's statement as a way for the government, especially the Ministry of Health to reduce public anxiety regarding the Corona case. This type of communication may be accepted by some audiences, but this can be likened to a double-edged knife where the other side can be deadly because this action is considered reckless and seems to underestimate the existence of this virus.

Kumparan.com also implements the same thing, namely applying complete coverage with $5 \mathrm{~W}+1 \mathrm{H}$, but they further highlight what and how aspects related to the excitement of the community responding to the Corona case. One example is the following news:

"The public is currently discussing the case of two Depok residents who are positive for the corona virus. The Minister of Health, Terawan Agus Putranto, then compared the excitement of the coronavirus with the flu which has a higher mortality rate. "(What) [11]

"Even though we have the flu that usually happens to us, coughs and colds have a higher death rate than this corona one, but why is this so exciting?" said Terawan at the Ministry of Health. (how) [12]

In Terawan's statement above, it is clear that he is trying to obscure an important event by trying to target other objects as important things that should be considered by the public. Because, it is not natural that currently in the middle of the whole country it is urgent to find solutions on how to suppress the spread of the Coronavirus, but the government, especially the Minister of Health, is trying to focus on seeing other problems that already have their own way of handling.

\subsubsection{Thematic}

In this case, kumparan.com reported Terawan's response to the development of the case of a positive Corona patient who received intensive treatment at RSPI Sulianti Saroso who had similarities with flu patients by using pronouns.

Two Depok residents are still being treated in the isolation room of RSPI Sulianti Saroso due to being infected with the corona virus. Minister of Health Terawan Agus Putranto said the treatment for both of them was the same as for patients with flu. [13]

In contrast, detik.com raises news with a similar title but provides a detailed emphasis on RSPI Sulianti Saroso care services for Corona patients. Yes, it is WHO accredited here, the isolation space is very good here, the position is in accordance with the standards and we do it all by means of the agreed SOP. [14] 
Meanwhile, in relation to the way journalists writing facts about the news, detik.com provided more detailed information on how the handling and treatment of Corona positive patients by hospitals that meet WHO standards and delivered directly by the Minister of Health, Terawan Agus Putranto. This was not done by kumparan.com, because they only reported the extent to which the positive patient could return home without explaining the procedure that had been carried out by the hospital.

\subsubsection{Rhetorical}

On detik.com, the language style is used carefully by using more formal and detailed language. In the term of graphic, detik.com used more illustrations than photos of Terawan Agus Putranto's face. In this case, the researcher saw the consistency of detik.com in reporting this information in a balanced manner by including additional information in the final paragraph.

Meanwhile, kumparan.com, in accordance with the company's vision, makes the news lighter and more relaxed with today's style, and the style of writing news delivered is also more relaxed by using lots of nonstandard language such as "no", "I see", "hio" , "Ndak" and so on. This is intended to make readers more comfortable and feel like talking everyday with friends or family. In addition, the editorial policy of kumparan.com always uses a personal photo of Terawan as an illustration of the news.
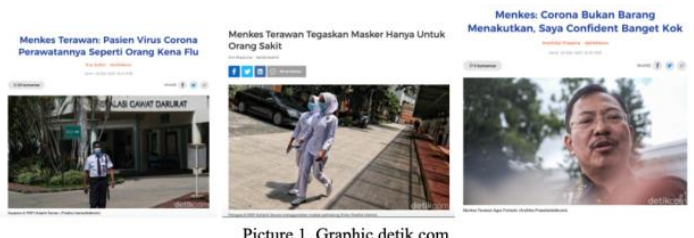

Picture 1. Graphic detik.com

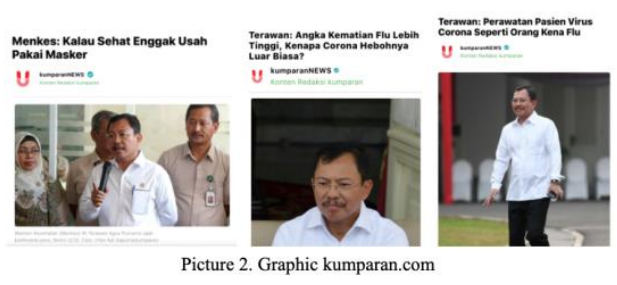

\section{CONCLUSION}

From the results of the framing analysis on the Indonesian government's public communication crisis in responding to the Covid-19 issue, especially by the Ministry of Health, it can be concluded that detik.com and kumparan.com have different points of view in constructing the existing reality. Detik.com chose to be more neutral by displaying additional information in the closing news section. Meanwhile, at kumparan.com, the researcher sees that editorial policy leads to lighter news coverage and is adjusted to today's readers who have a desire for news that is not long-winded and light. Kumparan.com is more focused on reporting Terawan Agus Putranto's response as Minister of Health in dealing with the Covid-19 case in Indonesia without adding other useful information.

In framing this case, basically the two media have used the same framing tools, namely syntax, script, thematic and rhetoric. However, both have their own options in highlighting the information they want to convey. Detik.com is more optimistic in using these four elements, of course in a subtle, firm and balanced way, while kumparan.com has emphasized the attitude and speaking style of Terawan Agus Putranto in responding to the existence of Covid-19 in Indonesia which is considered too underestimating.

Thus, the researchers saw that the Communication Crisis by Health Minister Terawan Agus Putranto was clearly framed by the two media, especially when viewed from the titles displayed by both of them.

\section{ACKNOWLEDGEMENT}

I express my gratitude to Dr. Phil. Lukas S. Ispandiarno, MA for an advice on this paper. And special thanks are given to Universitas Atma Jaya Yogyakarta for their assistance and support on research funding.

\section{REFERENCE}

[1] [11] [12] Prasetia, A. Menkes: Corona Bukan Barang Menakutkan, Saya Confident Kok. https://news.detik.com/berita/d-4922126/menkescorona-bukan-barang-menakutkan-saya-confidentbanget-kok/1, 2020. 
[2] Masluhah, S. Menkes Terawan Tegaskan Masker Hanya Untuk Orang Sakit. https://health.detik.com/berita-detikhealth/d4922354/menkes-terawan-tegaskan-masker-hanyauntuk-orangsakit?_ga=2.106564678.434351319.15873864241973175493.1556722223, 2020.

[3] Mustika, Rieka, Analisis Framing Pemberitaan Media Online mengenai Kasus Pedofilia di Akun Facebook. Jurnal Penelitian Komunikasi. 20(2), 2017, pp. 135-148. DOI: https://doi.org/10.20422/jpk.v20i2.159

[4] Athalia, M., Purnama, Hadi, Nugroho, Catur, Analisis Framing Pemberitaan Pembangunan Kereta Cepat Jakarta-Bandung. Jurnal J-IKA. 2(4), 2017, pp. 2458-2467.

[5] Moleong, J. Lexy, Metodologi Pendekatan Kualitatif. Bandung: Remaja Rosdakarya. 2002.

[6] Newman, W Lawrence, Social Research Methods Qualitative \& Quantitative Approaches. Boston: A and B, Pearson Education Inc. 2003.

[7] Eriyanto, Analisis Framing Konstruksi, Ideologi dan Politik Media. Yogyakarta: Lkis Pelangi Aksara. 2005.

[8] Eriyanto, Analisis Wacana: Pengantar Analisis Teks Media. Yogyakarta: Lkis Pelangi Aksara. 2002.

[9] Eriyanto, Analisis Framing Konstruksi, Ideologi dan Politik Media. Yogyakarta: Lkis Pelangi Aksara. 2005.

[10] Eriyanto, Analisis Wacana: Pengantar Analisis Teks Media. Yogyakarta: Lkis Pelangi Aksara. 2002.

[13] Irwinsyah. Fahrul, Terawan: Perawatan Pasien Virus Corona Seperti Orang Kena Flu. https://kumparan.com/kumparannews/terawanperawatan-pasien-virus-corona-seperti-orang-kena-flu1swpJ0SwIe1/full, 2020.
[14] Lutfha, M.D, Terawan: Angka Kematian Flu Lebih Tinggi, Kenapa Corona Hebohnya Luar Biasa?. https://kumparan.com/kumparannews/terawan-angkakematian-flu-lebih-tinggi-kenapa-corona-hebohnyaluar-biasa-1swuNpX1XXn/full, 2020. 